WALDEMAR GRACZYK

WNHiS UKSW, Warszawa

\title{
KSIĄŻKA XV-WIECZNA W OBECNYM ZASOBIE BIBLIOTEKI WSD W PLOCKU
}

Do II wojny światowej Biblioteka seminaryjna w Płocku posiadała ok. 400 inkunabułów. Była to kolekcja duża i cenna. W całości zbiór ten został wywieziony przez Niemców do Królewca. Do chwili obecnej żaden inkunabuł nie powrócił do prawowitego właściciela. Przechowywany obecnie zespół nie jest jednolity pod względem proweniencyjnym. Księgi w części trafiły do Płocka w latach 1947-1948 z Sandomierza. Tam bowiem w miejscowym Seminarium Duchownym przechowywano księgi po skasowanych w XIX wieku klasztorach żeńskich i męskich z terenu Królestwa Polskiego. Część tych zbiorów, dublety, dzięki życzliwości władz seminaryjnych, została przekazana po 1945 roku Bibliotece Seminarium Duchownego w Płocku. Jest to zbiór niewielki, ale pod wieloma względami interesujący. Dotyczy to zarówno autorów dzieł, dziedziny wiedzy, jakie reprezentują, wpisów proweniencyjnych, glos marginalnych, czy w końcu opraw. W sumie Biblioteka posiada 12 pozycji bibliograficznych w dziesięciu woluminach:

1. Statius Publius Papinius, Opera, pochodzące z weneckiej typografii Oktawiana Scotusa, wydane 2 grudnia 1483 roku$^{1}$;

2. Postilla super totam Bibliam, cum expositionibus Guillelmi Britonis et additionibus Pauli Burgensis replicisque Mattiae Doering, Mikołaja z Liry wydana przez Ulricha Zella w Kolonii około 1485 roku$^{2}$;

3. Sermones Thesauri novi de sanctis, Piotra de Palude, wydane w 1486 roku w Strasburgu w oficynie Typographus Paludani ${ }^{3}$.

4. Liber primus fratris Thomae de Kempis canonici regularis ordinis sancti Aug. De imitatione xpi et de temptum omni vanitatu mundi, wydane w Strassburgu w 1487 roku w oficynie Marcina Flacha ${ }^{4}$.

4. adl 1. Textor Guilielmus - Sermo de passione Christi ${ }^{5}$;

5. fragment Opera Arystotelesa, być może Logica vetus, cum commento: Copulata veteris Artis Aristotelis, wydane w Kolonii przez Henryka Quentella 13 sierpnia 1488 roku$^{6}$.

\footnotetext{
Inkunabuly w Bibliotekach Polskich (dalej IBP). red. A. Kawecka-Gryczowa, oprac. M. Bohonos, E. Szandorowska, t. 1, Warszawa 1970, poz. 5077 (def.), s. 863; BSemPł., Inc. sygn. 1.

2 W zbiorach płockich znajduje się tylko część druga tego dzieła. Por. BSemPł., Inc. sygn. 2.

IBP, t. 1, poz. 4370, s. 735; BSemPł., Inc. sygn. 3.

IBP, t. 1, poz. 3035, s. 502; BSemPł, Inc. sygn. 4.

BSemPł, Inc. sygn. 4, adl 1.

BSemPł, Inc. sygn. 5.
} 
6. Biblia wydana w 1489 roku w Strasburgu przez Jana Prussa';

7. Sermones de laudibus Sanctorum, wydane 23 lutego 1490 roku w Augsburgu przez Antoniego Sorga ${ }^{8}$;

8. De consolatione philosophie - Boecjusza, wydrukowane 31 października 1493 roku w Kolonii w typografii Henryka Quentella9;

9. Seneca Lucius Annaeus Iun. - Opera Philosophica et Epistolae, wydane 31 października 1492 roku w Wenecji w oficynie Bernardyna de Choris ${ }^{10}$;

9. adl. 1. Seneca - Tragoediae, cum commentis Gelli Bernardini Marmitae et Danielis Caietani $^{11}$;

10. Compendium iuris canonici, wydany w Strasburgu 9 lutego 1499 roku przez typografa Iordani - Ge. Hausnera ${ }^{12}$;

Mapa ośrodków drukarskich, które możemy określić na podstawie płockiej kolekcji inkunabułów obejmuje tylko dwa państwa ówczesnej Europy, w których sztuka drukarska rozwinęła się najszybciej i na bardzo wysokim poziomie. Są to: Niemcy i Włochy. Niemieckie i włoskie drukarstwo należało do najbardziej prężnych w XV-wiecznej Europie. W płockim zasobie obecne są dwa dzieła weneckie, trzy wydane w Kolonii, cztery w Strassburgu i jedno w Augsburgu. Podsumowując, proweniencje typograficzne inkunabułów płockich warto zaznaczyć, że są one dziełem warsztatów impresorskich rozlokowanych łącznie w czterech ośrodkach miejskich na terytorium wspomnianych krajów.

Cechą wspólną wszystkich omawianych druków XV - wiecznych, znajdujących się w zbiorach płockich jest to, iż wszystkie były drukowane w języku łacińskim, co w tym okresie jest w pełni zrozumiałe, bowiem dopiero wraz z Reformacją pojawi się potrzeba publikacji, szczególnie z dziedziny piśmiennictwa religijnego, w językach narodowych.

Choć jest niewielki zasób, ale interesująco przedstawia się jego zawartość treściowa, uwzględniająca wielkie bogactwo i różnorodność „twórczości” teologicznej swojej epoki. Jest rzeczą oczywistą, że biblioteki kościelne w pierwszej kolejności gromadziły księgi związane z Liturgią Mszy św., niezbędne do spełniania Służby Bożej, tj. Pismo św., jego liczne komentarze, pisma ojców Kościoła, dzieła kaznodziejskie. Dotyczy to zwłaszcza bogatej literatury średniowiecznej, gdzie granice podziału na poszczególne dyscypliny zacierają się całkowicie. W dziejach szeroko pojętej historii bibliotek kościelnych (katedralnych, kolegiackich, kanonickich czy klasztornych), Biblia jako źródło nauki objawionej była zawsze najważniejszą i bez wątpienia najbardziej rozpowszechniona księgą, do której odnoszono się z głębokim i należytym szacunkiem. Nie będzie przesady w określeniu, że w naszej kulturze przez całe wieki za najważniejszą księgę uważano Biblię. Lokalne środowiska kościelne przykładały dużą wagę do tego, by duchowni danego kościoła partykularnego byli w miarę dobrze zapoznaniu z problematyką biblijną. Nic zatem dziwnego, że z chwilą wynalezienia druku Ją drukowano

\footnotetext{
IBP, t. 1, poz. 1027, s. 169; BSemP1, Inc. sygn. 6.

IBP, t. 1, poz. 1411, s. 238; BSemPł, Inc. sygn. 7.

IBP, t. 1, poz. 1108 , s. 183; BSemPł, Inc. sygn. 8.

IBP, t. 1, poz. 4970, s. 842; BSemPt, Inc. sygn. 9.

BSemP1, Inc. sygn. 9, adl 1.

2 IBP, t. 1, poz. 1666, s. 279; BSemPł, Inc. sygn. 10.
} 
jako pierwszą ${ }^{13}$. W omawianym zasobie odnotowujemy obecność jednego egzemplarza Biblii, wydanej w 1489 roku w Strasburgu przez Jana Prussa ${ }^{14}$. W wiekach średnich jedną z głównych tendencji było między innymi zbliżenie ,świata Biblii” do człowieka i otaczającego go świata a także ułatwienie mu zrozumienia i przyswojenia jej treści, czemu służyła nauka zwana egzegezą. Warte podkreślenia jest to, że w omawianym zbiorze nie zabrakło najpopularniejszego w średniowieczu glosatora, franciszkanina i profesora Pisma Świętego na Uniwersytecie w Paryżu, Mikołaja z Liry. Postilla - jego jest komentarzem do Biblii, tekstu Wulgaty z uwzględnieniem tekstu hebrajskiego i komentatorów łacińskich. W zbiorach płockich znajduje się tylko część druga tego dzieła, a mianowicie Postilla magistri Nicolai de Lira super Parabolas Salomonis, prphetas maiores et minores et libros Machabeorum ${ }^{15}$.

Oprócz Biblii i komentarza w zasobie płockim znajduje się dzieło kwalifikowane do nurtu kaznodziejskiego. To Sermones Thesauri novi de sanctis, Piotra de Palude, wydane w 1486 roku w Strasburgu ${ }^{16}$. Zawiera ono kazania na święta roku liturgicznego. Dzieło to cieszyło się w Polsce dużą popularnością, stąd i jego obecność w wielu bibliotekach kościelnych. Warto podkreślić, że księgi tego typu spełniały funkcję praktyczną tzn. służyły pomocą w duszpasterstwie, w tym również do wygłaszania kazań. Egzemplarz przechowywany w płockim księgozbiorze, oprócz tego, że miał na przestrzeni wieków wielu właścicieli, to również był chętnie używany o czym świadczą licznie zachowane noty marginalne i podkreślenia całych fragmentów tekstu.

$\mathrm{Z}$ teologii dogmatycznej i moralnej wyodrębnił się dział teologii zwanej ascetyczną i mistyczną. Ze szkoły teologiczno-ascetycznej św. Bernarda z Clairvaux wywodzi się Jan Gerson, czołowa postać mistyki francuskiego średniowiecza, zaliczany do wybitnych teologów i filozofów tej epoki, zwany powszechnie doctor christianissimus ${ }^{17}$. Do tego nurtu pisarstwa religijnego zalicza się również Tomasza a Kempis. Dzieło tego autora, które odegrało olbrzymią rolę w rozwoju duchowości katolickiej, aż do chwili obecnej, znajduje się w płockim zbiorze inkunabułów. O autorstwie tego dzieła wymownie świadczy następujący zapis, umieszczony w incipicie: Liber primus fratris Thomae de Kempis canonici regularis ordinis sancti Aug. De imitatione xpi et de temptum omni vanitatu mundi ${ }^{18}$. Jest to ważne o tyle, iż w starszej historiografii przypisywało się Janowi Gersonowi autorstwo De imitatione Christi.

Dwa wyżej omówione działy (kaznodziejstwo i ascetyka) łączyło dzieło Sermo de passione Christi ${ }^{19}$. Zawiera ono Dialogi św. Anzelma z Canterbury (Dialogus de passione Christi) oraz dzieło De planctu Beatae Mariae Virginis, przypisywane św. Bernardowi z Clairvaux. Brak pewności co do autora dzieła sprawia, że w literaturze przedmiotu zwany jest jako Pseudo-Bernardus Claravalensis. Egzemplarz był w częstym użyciu, świadczą o tym podkreślenia licznych fragmentów tekstu i obfita glosa marginalna.

W analizowanym zbiorze odnotować należy trzy dzieła z zakresu filozofii. Jest to o tyle zrozumiałe, że księgi te gromadzone w przeszłości przez różnego rodzaju instytucje kościelne

13 W. Graczyk, Kulturowo-religijna rola bibliotek kościelnych, „Archiwa Biblioteki i Muzea Kościelne”, 83/2005, s. 23-24.

14 BSemPł, Inc. sygn. 6.

15 BSemPł., Inc. sygn. 2.

16 BSemPł., Inc. sygn. 3.

17 S. Wielgus, Gerson Jean, w: Encyklopedia Katolicka, t. 5, Lublin 1989, kol. 1018-1020.

18 BSemPł, Inc. sygn. 4.

19 BSemPt, Inc. sygn. 4, adl 1. 
miały spełniać przede wszystkim rolę formacyjną i duszpasterską. Najczęściej traktaty filozofów starożytnych i średniowiecznych gromadziły biblioteki akademickie. Najwybitniejszym filozofem starożytności, chętnie komentowanym przez myślicieli średniowiecza był Arystoteles. W bibliotece seminaryjnej znajduje się fragment (17 kart) inkunabułu, który posłużyły w przeszłości introligatorowi jako materiał makulaturowy do wykonania okładzin jednego z tomów Akt kapituły płockiej z lat 1562-1570. Na karcie 132 widnieje nazwisko Gilberti Porretani, a na jej odwrocie nagłówek Sex Principia. Dlatego można przypuszczać, że prawdopodobnie jest to fragment Opera Arystotelesa, być może Logica vetus, cum commento: Copulata veteris Artis Aristotelis, wydanego w Kolonii przez Henryka Quentella 13 sierpnia $1488 \mathrm{roku}^{20}$. Z pogranicza starożytności i średniowiecza wywodzi się Boecjusz (ok.480ok.524), autor rozpowszechnionego w średniowieczu dzieła De consolatione philosophiae, który podejrzany o działalność spiskową przeciwko królowi Ostrogotów, Teodorykowi, napisał je w więzieniu, oczekując na wyrok. W dziele tym Boecjusz sformułował definicję filozofii i na podstawie różnych klas bytów przedstawił klasyfikację nauk, podporządkowanych filozofii. Porządek rzeczy uzależniał od opatrznościowego działania Bytu Doskonałego. W omawianej bibliotece przechowywany jest jeden egzemplarz wydrukowany 31 października 1493 roku w Kolonii w typografii Henryka Quentella ${ }^{21}$. Do pogranicza filozofii i epistolografii należy zaliczyć dzieło Seneki Opera Philosophica et Epistolae ${ }^{22}$. W wydaniu zbiorczym tzw. klocku wydawniczym znajduje się jeszcze tego samego autora: Tragoediae, cum commentis Gelli Bernardini Marmitae et Danielis Caietani ${ }^{23}$.

Z przechowywanych inkunabułów jeden dotyczy dziedziny prawa kościelnego. Trzeba podkreślić, że różne instytucje kościelne posiadały kompletne zbiory, jak i poszczególne części prawa kanonicznego i cywilnego. Znajomość zagadnień prawnych przede wszystkim z prawa kościelnego była niezbędna do pracy duszpasterskiej. Biblioteka płocka posiada Compendium iuris canonici, wydany w Strasburgu 9 lutego 1499 roku. Wydawnictwo to spełnia funkcję słownika wyjaśniającego różne zagadnienia z zakresu prawa kanonicznego.

Zatem ten niewielki zasób obejmuje kilka obszarów wiedzy: biblistyka, kaznodziejstwo, ascetyka, filozofia i prawo.

Inkunabuły przechowywane obecnie w zbiorach Biblioteki Wyższego Seminarium Duchownego w Płocku nie są jednolitym proweniencyjnie zespołem ksiąg. Księgi pochodzą z instytucji kościelnych i osób indywidualnych w tym duchownych. Na części z nich nie zachowały się żadne wpisy pozwalające na określenie poprzedniego właściciela. W sumie zapisy własnościowe zachowały się na pięciu woluminach. Niekiedy są tak dokładne, że pozwalają odtworzyć drogę, jaką przebywało dzieło na przestrzeni wieków. Przykładem może być Sermones Thesauri novi de sanctis, Piotra de Palude, które najpierw należało do proboszcza w Jadamowie, ks. Wojciecha Okręglickiego. Fakt posiadania własnoręcznie odnotował: Sum Alberti Okręglicij parochi in Jadamow Anno Dni 1549. Zapewne legatem testamentowym przekazał je Melchiorowi z Żywca: Possesor Melchior Żywiecz A.D. 1600, zaś ten w 1643 roku Walentemu, prepozytowi szpitala p.w. św. Anny. Ostatnim udokumentowanym właścicielem był ks. Krzysztof ze Staszowa: Ex libris Ioannis Christophori

20 BSemPł, Inc. sygn. 5.

21 BSemPł, Inc. sygn. 8.

22 BSemP1, Inc. sygn. 9.

23 BSemP1, Inc. sygn. 9, adl 1. 
de Staszow actu praesbiteris. Można z dużą dozą prawdopodobieństwa powiedzieć, że ze Staszowa trafił on w okresie kasat do Sandomierza a stamtąd po 1945 roku do Płocka.

Drugim inkunabułem, gdzie można wskazać na wcześniejszych właścicieli jest Sermones de laudibus Sanctorum. Księga pozostawała własnością dominikanów, o czym świadczą zapisy: (1) Iste [...] donatus est fr[atr]i Alexio [Zincid?...] a fr[atr]e Floriano Posnanensi; (2) Fr[ater] vero Alexius donavit conventui Plocensi sub A.D. 1606. Zapewne po kasacie klasztoru dominikanów w Płocku na początku XIX wieku, księga została przeniesiona do pobliskiej biblioteki katedralnej a stamtąd w XX wieku do nowo wybudowanego gmachu biblioteki na terenie seminarium duchownego. Stąd nasuwa się odpowiedź na pytanie, dlaczego dzieło ocalało i nie znalazło się wśród wywiezionych do Królewca? Zapewne dlatego, że fizycznie nie było go w tym czasie w zbiorze. Prawdopodobnie korzystający z niego duchowny w sposób niezamierzony uratował je przed wywózką.

Trzecią księgą, w której został imiennie odnotowany właściciel jest De consolatione philosophie Boecjusza. Należała ona wcześniej do bliżej nieznanego Andrzeja, co potwierdza mało dokładny wpis Andreas Meinreus, umieszczony pod drzeworytem na dolnym marginesie karty tytułowej. Zdecydowanie więcej możemy powiedzieć o wcześniejszych właścicielach kolejnego inkunabułu pt. Opera Philosophica et Epistolae. Księga była wcześniej własnością bernardynów w Przasnyszu (klasztor fundowany pod koniec XVI w.), o czym świadczy zapis na karcie tytułowej: Loci Prasnensis 20 Aprilis 1604, a nad nim późniejszy zapis inwentarzowy VII 9.2. Dzieło to było jednym z pierwszych, tworzących zalążek biblioteki klasztornej. Zapewne przez cały czas - aż do kasaty klasztoru w połowie XIX wieku znajdowało się w klasztorze, zapewne po kasacie klasztoru zostało przewiezione do Płocka.

I ostatnią księgą, w której wcześniejsi właściciele odnotowali fakt swego posiadania jest Compendium iuris canonici. Odnotowanych jest w niej trzech wcześniejszych właścicieli. Byli to zapewne duchowni, którym znajomość przepisów prawa kościelnego była niezbędna w pracy duszpasterskiej: Abraham Sokoliński 1619; Anno 1664 die 7 decembris hunc librum posedit Ioannes Polański, i ostatni, prawdopodobnie już XVIII - wieczny wpis: Ex libris Alberti Constantini Wozniowski praepositi Scavinensis Pl[e]ban[us] Tynecensis.

Kilka uwag należy się również oprawom inkunabułów płockich. Oprawy w części pochodzą z okresu druku inkunabułu, w części zaś z okresu późniejszego. W większości oprawę inkunabułów stanowi deska lipowa lub bukowa, na którą naciągniętą brązową skórę. Na powierzchni wielu opraw widoczne są tłoki ślepe z elementami geometryczno-floraturowymi (np. Opera, Statiusa Publiusa Papiniusa). Powierzchnia skóry bywa często podzielona na prostokątne pola $\mathrm{z}$ dobrze widocznym ślepym wyciskiem lilii w romboidalnym polu na przednim licu oprawy. W analogicznym romboidalnym polu na tylnym licu oprawy zachowane są tłoczone ślepo rozety (np. De imitatione Christi). Na przedniej okładzinie wykonano podział na środkowe pola, składające się z meandrów, ze środkowym tłokiem kwiatowym i podziałami filetą i powtarzającym się rzędem tłoków: okrągły roślinny i lilia w wydłużonym rombie. Na przedniej i tylnej desce okładziny zachowały się wcięcia po zapinkach (Sermones de laudibus Sanctorum).

Schemat dekoracyjny występujący w oprawach tego niewielkiego zespołu to okalające zwierciadła okładzina, odciśnięte radełkiem bordiury, mające zazwyczaj wici roślinne, czy motywy arabesek. Dekoracje centrum zwierciadeł okładzin stanowią odciski kilku rodzajów plakiet lub tłoków i są one z reguły tłoczone na ślepo zaś pola ich wypełnione są symetrycznie uformowanym elementem tzw. roślinnej plecionki (np. De consolatione philosophie). 
Bardzo interesującą oprawę posiada dzieło Opera Philosophica et Epistolae. Obie okładziny mają tłoczony bogaty ornament. Na górnym polu wierzchniej okładziny widoczny jest wycisk introligatorski OPERA SENECAE. Przednia okładzina ma potrójną bordiurę, w całości wypełnioną tłoczeniami, zewnętrzna, zdecydowanie najszersza została podzielona na romby z wyobrażeniem smoka. W narożnych polach wyciśnięty jest stylizowany ornament roślinny. Na drugą bordiurę składają się elementy wici roślinnej; wewnętrzna bordiura przedstawia splot takiej wici okalający centralne pole, które podzielono na meandry. Zawiera ono w każdej powstałej przestrzeni dwa identyczne wzory, stylizowanych liści umieszczonych pojedynczo na przemian. Grzbiet bloku o czterech polach, wydzielonych podwójnymi zwięzami, zdobi ornament meandrowy z tłokiem roślinnym we wnętrzu.

W tym niewielkim zbiorze możemy spotkać także oprawy późniejsze. Taką posiada dzieło Compendium iuris canonici. Stanowi ją wzmacniana tektura, na którą naciągnięto jasnobrązową skórę. Pole przedniej i tylnej oprawy jest identycznie zdobione. W centralnym miejscu umieszczony jest owalny medalion, w jego obramieniu głębokie tłoczenia floraturowe.

Dwa dzieła spośród tego niewielkiego zbioru otrzymały oprawy podczas prowadzonych na przełomie XX/XXI w. prac konserwatorskich. Są to: fragment Opera-Arystotelesa oraz Biblia.

Reasumując, należy podkreślić, że piętnastowieczny księgozbiór płocki, mimo że niewielki i niejednolity proweniencyjnie w pewnym sensie odzwierciedla umysłowość, kulturę ducha i zainteresowania intelektualne duchowieństwa polskiego, tak diecezjalnego jak i zakonnego. Ten krótki przegląd zawartości jego treściowej wskazuje na to, iż był to typowy księgozbiór charakteryzujący się tym, że zaspokajał potrzeby duchownych w zakresie wykształcenia, jak również miał służyć kształtowaniu świadomości religijnej wiernych, czyli tzw. duszpasterstwu. Funkcja praktyczna księgozbioru dotyczyła tej części literatury teologicznej, która wychodziła poza ramy spekulatywnych rozważań, a miała na względzie nade wszystko praktyczne potrzeby wiernych. Całość zasobu księgozbioru skoncentrowana jest wokół czterech wielkich grup treściowych: Pisma św., teologii, prawa i filozofii. Autorzy tych dzieł byli najwybitniejszymi przedstawicielami średniowiecznej nauki.

\section{The fifteenth century book in the present collection of the library of seminary in Plock Summary}

The kept collection of incunabula is not uniform in terms of their origins. Although this is a small collection, in many ways it is interesting concerning both authors, areas of their knowledge, notes of origin or their binding. The library has in total twelve bibliographical positions in ten volumes. They are the work of workshops located in four urban centres: Venice, Cologne, Strasbourg and Augsburg. All of the collection of books are concentrated around four major groups: Scripture, Theology, law and philosophy. The authors of those works were the most prominent representatives of medieval science. Part of the incunabula's cover are from the period of the book's print (turn of fifteenth and sixteenth century), part of them are from the later period.

Keywords: Płock, library, incunabulas, books

Nota o Autorze: ks. prof. zw. dr hab. Waldemar Graczyk, dyrektor Instytutu Nauk Historycznych w Uniwersytecie Kardynała Stefana Wyszyńskiego w Warszawie i kierownik katedry Historii Średniowiecza w tymże Instytucie. Prowadzi badania nad dziejami Mazowsza, polskim monastycyzmem i historią książki. 